\title{
Family Matters: Neoliberal Narratives of Welfare Capitalism in Undercover Boss
}

\author{
Sean Brayton \\ Correspondence: Sean Brayton, Associate Professor, Department of Kinesiology and Physical Education, University of \\ Lethbridge, Canada
}

Received: September 2, 2014 Accepted: September 16, 2014 Available online: October 8, 2014

doi:10.11114/smc.v2i2.501

URL: http://dx.doi.org/10.11114/smc.v2i2.501

\begin{abstract}
This paper examines media representations of labor and working conditions under late capitalism. Specifically, it presents an interdiscursive analysis of the "reality" television series Undercover Boss, drawing attention to themes that reflect and react against the vicissitudes of the Great Recession and recent labor struggles within service and hospitality industries in the US. With corporate "generosity," the series belies recent protests by presenting individual rather than structural solutions to problems in the workplace. The act of corporate "benevolence" and rhetoric of the "family" resemble the tactics of what is historically called welfare capitalism, which aimed to forestall government labor regulations, disarm organized labor and discipline the worker. All of the employees rewarded in the series embody neoliberal ideals of the citizen-subject; they are self-disciplined, abstain from union activity and rely on the company rather than government assistance for wellbeing. But if Undercover Boss is approached as a serial melodrama rather than merely a "makeover," it may support the claims of recent labor movements. The series documents and circulates many of the working conditions and structural inequalities faced by fast-food, hospitality and retail workers under late capitalism. In effect, Undercover Boss contains a salient dialectic: the "benevolent" boss that "resolves" the quandaries of late capitalism can only emerge against a backdrop of adverse working conditions, which the series is obliged to address in passing but also in perpetuity for its own success.
\end{abstract}

Keywords: labor, welfare capitalism, neoliberalism, Undercover Boss, reality television, Great Recession

\section{Introduction}

On 15 May 2014 fast-food workers staged walkouts and took to the streets of 230 cities in thirty-two countries across six continents. Described as the largest strike in the history of the fast-food industry, the walkouts epitomized a growing "minimum wage movement" - dubbed "Fight for Fifteen" in the US - and sought to draw international attention to exploitative labor practices, subpar wages and the right to unionize without employer intimidation. As a McDonald's employee and activist in Memphis, Tennessee, exclaimed, "We've gone global" (Horovitz, 2014). Funded by the Service Employees International Union (SEIU), the protests in the US began in 2012 as part of a sweeping grassroots campaign demanding the legislation of a $\$ 15 /$ hour minimum wage (hence the Fight for Fifteen) and have been described as "a defibrillator to a dying American labor movement" (Gupta, 2013). In December 2013, fast-food employees were joined by service and retail workers at Walgreen's, Macy's and Sears, striking across 100 cities to direct national interest in combating income inequality, what US President Barack Obama called "the defining challenge of our time" (Gabbatt, 2013). As The New York Times observed, "These strikes carry the flavor of Occupy Wall Street protests and are far different from traditional unionization efforts that generally focus on a single workplace" (Greenhouse, 2013). Alongside a wave of walkouts and strikes in North America-from hospitality staff at Disneyworld and Walmart employees on "Black Friday" to machinists at Boeing aviation and grocery workers at Loblaws in Canada - it seems that both residual and emergent labor struggles are amplified in the economic fallout of 2008 and the Great Recession.

While the Great Recession has defined the political climates of North America and Europe since 2008, it now reverberates across popular culture, especially film and television. Even Hollywood has produced a welter of "Bust Culture" pictures, including The Other Guys (2010), The Company Men (2010), Tower Heist (2011), Margin Call (2011) and Assault on Wall Street (2013) (Boyle \& Mrozowski, 2013). While such films are firmly embedded in the post-2008 economic setting, actual working conditions and labor politics are often less pronounced, providing at best a narrative backdrop. In the realm of "reality" television, however, images of working people abound. Programs like Ax Men 
(2008), Black Gold (2008), American Loggers (2009) and Coal (2010), for instance, detail the dangerous working conditions of physical labor. And yet they tend to provide a nostalgic celebration of rugged white masculinity incongruous with the current complexion of the working class.

A more "multicultural" portrait of labor appears in the CBS series Undercover Boss (2010), a reality show produced and broadcast in the US, Canada, Australia, Britain, France, Germany, Spain, Italy, Austria and Norway. Debuting at the height of widespread outrage at Wall Street executives and corporate bailouts, Undercover Boss (US) depicts company presidents who dress in disguise to learn firsthand from their employees how to improve working conditions and optimize productivity. As "philanthropic television," each episode ends with the boss revealing his or her true identity only to reward deserving employees with various prizes, from exotic vacations and flying lessons to costly medical procedures and college scholarships. For compelling reasons, the series has been widely criticized as a paragon of paternalism, a "capitalist fairy tale" that panders to audience emotion and corporate advertising (Havrilesky, 2010). Given the "global" popularity of the series, there are surprisingly few scholarly analyses of Undercover Boss, leaving some lingering questions: What do the increasing narratives of labor on reality television, specifically those of the prolific Undercover Boss franchise, tell us about late capitalism during the Great Recession? How does corporate "benevolence" in Undercover Boss ensnare the worker in residual and emergent ways? What gaps or fissures exist in the narrative and how do they complicate and contradict the series as a "capitalist fairy tale"?

To address these questions, I use an interdiscursive analysis that explores how the series reflects and reacts against the vicissitudes of the Great Recession and recent labor struggles across North American service industries. From this method, competing messages of the series become apparent. While Undercover Boss taps into a discourse of "benevolence" to discipline workers in ways that resemble welfare capitalism of a bygone era, it relies on and exposes the same harsh conditions of production it aims to improve. Although the series presents a myopic "makeover" I explain how Undercover Boss also resembles a serial melodrama, which shifts the coordinates of analysis to expose an aporia in the series' own rhetoric of labor-capital relations. Although the boss misunderstands problems in the workplace as isolated events or misfortune, the series illustrates how adverse working conditions and pittance for pay are inherent to late capitalism. Although Undercover Boss proposes personal solutions to structural inequalities that belie the objectives of the "minimum wage movement," its incessant attention to workers' dissatisfaction may complement rather than counteract recent protests by service workers in the US - the labor demographic that largely defines the "cast" of the series.

\section{Work, Class and "Reality" Television}

From game shows and makeovers to dating and talent contests, the mode of production and content of reality television is often laden with class politics (Hearn, 2006; Ouellette \& Murray, 2004; Andrejevic, 2004; Raphael, 2004). As Heather Nunn and Anita Biressi point out, "Far from diverting attention away from important sociopolitical debates, reality programming in fact translates them into resources, directives, and models of how to live better within a neoliberal context" (2013). This occurs, of course, in rather complex and contradictory ways. Programs like The Apprentice (2004) Big Brother (2000) and Survivor (2000), for instance, often obfuscate the pitfalls of late capitalism (flexible accumulation and precarious labor conditions) by amplifying the attributes of unfettered competition and rewarding ruthless individualism, or what Oliver James calls "affluenza" (2008). Other programs like The Secret Millionaire (2006) The Benefactor (2004) and Undercover Boss, for example, combine "makeover" formats with philanthropic narratives to enable wealthy individuals to undergo personal awakenings through their generosity towards the "deserving poor" (Nunn \& Biressi, 2013). In both cases, the content of reality television and its cut-rate methods of production can be said to support a neoliberal "social structure of accumulation," which aims to "(temporarily) stabilize class contradictions” (Wolfson, Martin \& Kotz, 2010).

In many ways, reality television's investment in neoliberal maxims of self-improvement and upward social mobility are exemplified by the "makeover" series. With "experts" improving everything from automobiles, restaurants and homes to relationships, parenting skills and the body, the makeover is consistently rooted in a fantasy of social mobility. As Helen Wood and Bev Skeggs suggest, "Many of the programmes are structured through class relations where the working class are exposed as inadequate and in need of training in middle or upper-class culture" (2008). Obvious examples include The Swan (2004), Queer Eye for the Straight Guy (2003-2008), What not to Wear (2003-2013) and Extreme Makeover (2002-2007), where participants ostensibly move from "rags" to "riches" by undergoing physical and sartorial transformations that "universalize middle-class lifestyles" by promoting urban affluence, "metrosexuality" and personal responsibility (Wood \& Skeggs, 2008). Similar fables underwrite Extreme Makeover: Home Edition (2003-2012) in which struggling working-class families (most of which are non-white) receive new homes customized by a team of good Samaritans led by host Ty Pennington. And yet the recipient families, as John McMurria points out, often "conform to the ideals of neoliberal citizenship through working long hours in moderate- to low-paying service sector jobs with inadequate health coverage without complaint" (2008). 
If the working class is often an object of derision and development in some reality television programs, it is also the subject of approval and adulation in others. Since 2008 a glut of "paid labor shows" has appeared on television-including "docudramas" like Ax Men, Black Gold and Coal-that celebrate working-class bodies, particularly those of white men. As I have argued elsewhere, "paid labor shows"-which surged in popularity after the "global economic meltdown"-are "premised on the visibility of working-class bodies", which are situated as both heroic and expendable in logging, drilling and mining industries (Brayton, 2012). Such problematic "retro masculinities" that emerge through "narratives of physical labor [and] danger" also provide "a latent form of class conflict that both enables and constrains a more comprehensive understanding of economic struggle" (Brayton, 2012). What is most jarring about such labor narratives, however, is the general absence of women and workers of color that define the increasingly "multicultural" complexion of today's working class, most notably in North American service and manufacturing industries.

It is within the context of the Great Recession and the subgenre of "paid labor shows" that we find Undercover Boss, a series that provides perhaps the most assorted and "multicultural" but no less problematic glimpse of the American workplace. In light of its enduring popularity, and the voguish academic interest in reality television, Undercover Boss is the subject of surprisingly few scholarly analyses. In one insightful critique, Lyell Davies, for instance, explains how Undercover Boss presents "no sense that the conditions it depicts deserve wide-reaching reform" yet the workers' disclosure of such conditions to the boss-in-disguise "may be illustrative of an embryonic form of class solidarity" (2013). Davies is especially suspicious of the isolated ways that problems in the workplace are purportedly solved in the "reveal sequence" where the boss "dispenses rewards" (2013). Here "gift-giving" is presented as "socially transformative" and provides the "narrative closure" of a makeover show (Ferrier, 2005). In his brief but poignant review of the series, Steve Striffler adds that Undercover Boss is essentially about "charity, not change" and caters to the interests of the boss rather than the workers; "the viewer gets only the perspective of the boss, and only the boss is presented with any complexity" (Striffler, 2010). Both Davies' and Striffler's commentaries also address the free "immaterial labor" of workers that provide narrative content but receive no payment from the television network. To this end, Undercover Boss may be more appropriately named "punking the proletariat." While Davies and Striffler offer slightly different lines of critique, they tend to agree on the isolated ways in which Undercover Boss presents and attempts to resolve structural problems of late capitalism. In other words, the series is understood (and critiqued) as intended, that is, an episodic "makeover" of both boss and workplace that promises closure and containment that supplants any need for "a movement towards economic justice" (Davies, 2013).

\section{Method}

To explore the "cultural work" done by Undercover Boss and to build on the few existing studies of the series, I use what Norman Fairclough calls an "interdiscursive analysis," one that approaches the text as a repository of "different discourses, genres and styles" (2003). As readers will recall, this particular method examines how the language and sign-systems of texts help to "produce and reproduce relations of domination" (Fairclough, 1995). Moreover, an interdiscursive analysis explains and interrogates the meanings of a text within specific socioeconomic settings, such as the Great Recession. As a result, it helps to unpack how Undercover Boss "comes to be seen as transparently reflecting economic realities rather than constructing them in a particular way" (Chouliaraki \& Fairclough, 1999). Teasing out these realities involves attending to what Fairclough describes as syntagmatic and paradigmatic relations of a text, that is, messages that are both present and absent (2003). In the hit reality television series, some interesting trends emerge across both "axes" of representation.

While audience reception is an important aspect of explaining Undercover Boss as a cultural phenomenon, I am most interested in how the series provides competing interpretive resources that both help and hinder a wider understanding of the crises of capitalism during the Great Recession. Using an interdiscursive analysis, then, I examine the first four seasons (2010-2014) of the US version of the series. Within this sample, some glaring themes unfold that calibrate and complicate the boss-worker relationship. In fifty-nine original episodes, fifty-nine separate bosses are featured. However, there are only six women (all of whom are white and only one is actually a CEO), two white European immigrants (from Denmark and Norway, respectively), four Latinos and two black men (one is Mayor of Cincinnati and the other is a Chief Marketing Officer). In other words, ninety percent of the bosses are either white or male. There are, evidently, no women of color featured as either CEO or executives. Conversely, the demographics of wage labor are overwhelmingly comprised of women and workers of color (mostly black and Latina/o), especially in service and hospitality jobs.

A detailed deconstruction of Undercover Boss, however, reveals a central dialectic of the series: despite the onscreen attention to labor, the series is ultimately interested in corporate branding and the emotional transformation of the boss, which can only emerge, however, by attending to a crisis condition of inequality and exploitative working conditions of late capitalism. To draw out the dialectic, I begin by shifting perspective on the program's genre from makeover to 
serial melodrama. I explain how the narrative of the "benevolent" boss that enables the makeover myth is subsidized only by the exposition of adverse working conditions, which Undercover Boss is compelled to "serialize" for its own success. As a serial melodrama, then, the program's exposure of the quandaries of late capitalism has the unintended consequence of encouraging viewers to identify problematic patterns across service, hospitality and manufacturing industries. I then describe how the solutions proposed by each boss resemble neoliberal versions of what is historically called welfare capitalism, a flawed attempt to discipline labor and contain class conflict through "goodwill" whilst avoiding government labor regulations and rabblerousing unions. In its entirety, Undercover Boss celebrates the capitalist as a "healing hand" that resolves the problems of a system from which s/he benefits most, thereby presenting a critical contradiction in the program's portrait of "capitalist realism" (Fisher, 2009).

\section{Labor and Capital in Undercover Boss}

The narrative format of Undercover Boss is rather basic and predictable: each episode begins with a corporate CEO or executive expressing concerns of productivity to senior management and the viewer. We then learn of the company's earnings and employment as well as the humble upbringing of the boss, who is shown at a sprawling mansion embracing and interacting with his or her family. Here the audience is informed of the boss's sincerity and commitment to both family and business, which often converge throughout the episode. After trading a business suit for work boots and a uniform, the boss adopts a canard of unemployment and the recession to explain to coworkers how the invasive cameras are merely shooting a documentary on "entry-level employment" or a reality television show in which two recruits compete for a job. Over the next seven days, the boss visits various departments within the company-from manufacturing and distribution facilities to customer service and maintenance crews - to weed out hiccups in production and discover the workers' own perceptions of the company and its operations. The viewer gains cathartic pleasure in watching the boss's mishaps and physical exhaustion in performing routines of the workday. After learning the hardships of "coworkers"-from economic woes and illnesses to long hours and unpaid childcare - the boss typically meets with company board members to vet certain rewards for hardworking employees. In what Davies calls the "final 'reveal' sequence", the boss presents his true identity only to reward "deserving" employees and reprimand "undeserving" ones (2013). The recipients of the boss's charity respond with emotional gratitude, which is followed by a company "pep rally" where the boss discloses his or her own personal transformation in (momentarily) experiencing the daily travails of working folks.

\subsection{Serializing the Problems of Late Capitalism}

Undercover Boss is rather candid in its attempt to offset widespread anger and frustration towards "one-percenters" and the villains of the Great Recession in the US. Episodes in Season One open with the narrator's monologue:

The economy is going through tough times. Many hardworking Americans blame wealthy CEOs out of touch with what's going on in their own companies. But some bosses are willing to take extreme action to make their businesses better.

The bosses of the series, then, are situated as exceptional in the first season, but increasingly commonplace in the second season as "More and more bosses are willing to go to extreme measures to help their companies and employees succeed". (Incidentally, the opening narration of the Great Recession is dropped by the third season.) The sincerity and generosity of the boss culminates in the "gift-giving" ceremonies at the end of each episode, which includes a variety of prizes, strategies and "remedies" to the struggles faced by employees. While several critics of the series tend to focus on the bedazzled gifts of exotic vacations, scholarships and automobiles, many of the resolutions involve initiatives and programs led by the workers themselves. From wellness programs and leadership seminars to mentorships and advanced training, the employees often find themselves embroiled in initiatives that require unremunerated labor and include additional surveillance from corporate headquarters. Nevertheless, the employees respond with gratitude at the generosity and resolve of "caring bosses." Indeed, "the gift-giving is particularly satisfying, providing narrative closure, because it is represented as socially transformative" (Ferrier, 2005).

While Undercover Boss certainly contains aspects of the makeover program, it also resembles a serial melodrama which, by definition, undermines the prescribed messages of closure and containment in each episode. While the melodramatic features are relatively obvious - from repeated close-ups and tales of "morality" to scenes of emotional gratitude-the "serial" aspects of Undercover Boss are perhaps less conspicuous. Borrowing from daily comic strips and radio programs of the 1930s and 1940s, the television serial provided "sustained settings and casts of characters dealing with ongoing scenarios, but generally avoid[ed] plotlines that created open-ended narrative situations demanding resolution" (Mittell, 2013). Although the serial contains an ensemble of regular characters, Undercover Boss presents a set of recurring character types - workers and bosses - which invite the identification of certain patterns. Issues of pay, health benefits, childcare and respect, for instance, cut across the industries and episodes and are equally pertinent to airline attendants, bakers and mechanics as they are to deliverymen, fast-food staff and lifeguards. Perhaps Undercover Boss is 
best understood as a "serial labor text" that outlines persistent themes and broad settings of late capitalism rather than specific characters (though some bosses and employees return for additional episodes); factory employees, service workers, cooks and cleaners all appear to the viewer through the same narrative, allowing the viewer to spot situational if not socioeconomic similarities among workers. Here "The multiplicity of specific concrete forms of labor remain different, but it tends to accumulate an ever greater number of common elements" (Hardt \& Negri, 2004).

As much as the boss of each episode perceives problems of the workplace as isolated and manageable incidents, the series itself suggest otherwise, that exploitative practices are endemic and thus intrinsic to late capitalism. Indeed, the caring boss and deserving worker can only emerge against a backdrop of difficult working conditions, which are serialized in Undercover Boss: the \$8/hour wages of custodial workers at Churchill Downs, bakers at Philly Pretzel Factory and food servers at Checkers; the pay cuts of airline attendants at Frontier; the lack of recognition and respect for vineyard workers at Kendall-Jackson and mechanics at the City of Cincinnati; double-shifts and long hours of waitresses at Lucky Strike and Great Wolf Lodge as well as maintenance workers at Diamond Resorts; lack of childcare and health benefits voiced by workers at Herschend Family Entertainment, Kendall-Jackson, O'Neill Clothing and Roto-rooter; abusive management at Hooters and Checkers; health problems and substance dependency issues of employees at Waste Management, DirectTV and 7-11; homelessness and housing issues with staff at Adventure Aquarium, MGM Grand, Modell's Sporting Goods and Johnny Rockets; the perils of "temp work" by health care aids at Brightstar; the stress of outsourcing and plant closures faced by workers at Mack Trucks and Chiquita; daily physical exhaustion of working bodies at Synagro, ABM cleaning services and Choice hotels. While debt and health problems are regular hardships of the "cast" of Undercover Boss, the strains of employment on family relationships are prioritized.

Many of these problems underwrite Fight for Fifteen, Fast Food Forward and other "alt-labor" movements campaigning for increasing the minimum wage in the US, which is currently set at $\$ 7.25 /$ hour, or approximately $\$ 15,000 /$ year for full-time employment (Gabbatt, 2013). As SEIU President Mary Kay Henry explains, "The economy is creating jobs that people can't support their families on" (Greenhouse, 2013). One fast-food employee in Detroit, like many other workers in a service industry that employs more than four million Americans, stated plainly, "On what I'm earning right now you have to choose between paying your rent and eating the next day" (Greenhouse, 2013). From abject poverty, homelessness and household debt to pittance wages, lack of health insurance and respect at the workplace, service workers across the US may find their causes supported in the disparity of low-wage labor in Undercover Boss. Unlike the cast of the television series, however, workers at the heart of the minimum wage movement are not content with cosmetic revisions to a fundamentally exploitative mode of production. As a labor activist and employee at Burger King observed, "These companies aren't magically going to make our lives better" (Greenhouse, 2013). In other words, the exotic vacations, automobiles and lump payments for family wellbeing that we find in Undercover Boss are insufficient band-aid solutions to a systemic problem in and across service, retail and hospitality industries in North America. The central problem for many of these workers is economic inequality, which is reflected and refracted by the program in various ways.

In Undercover Boss, we learn of the workers' families and economic struggles through confessions to the disguised CEO, who exploits their trust and rarely breaks character. Employees at Adventure Aquarium, MGM Grand, Modell's Sporting Goods, Johnny Rocket's and Moe's Southwest Grill explain the plight of being homeless single parents struggling to find shelter and steady work and consider their current employers "lifesavers." Given a "second chance" by Boston Market after experiencing "trouble with the law," a grateful employee claims that he would "do anything for the company." A desk clerk at Comfort Suites and an assembly-line worker at Unifirst describe their respective parents' rejection while pregnant in their teens, both of whom are thankful for their current jobs. While employment itself is often depicted as evidence of corporate goodwill in lean economic times, the bosses are heart-stricken by the struggles of their employees. At the end of the workday, bosses retreat to their budget motel rooms and microwavable dinners, expressing to the viewer their fatigue, muscle soreness and utter surprise that "anyone would get up so early to do this work." As they remove the trite working-class costume of "bad hair, bad teeth, bad clothes", they often quip how "every bone in their body aches" and make requisite phone calls to loved ones (Striffler, 2010). It is not uncommon for bosses to become overly emotional while reflecting on the struggles of their employees. As the CEO of Herschend Family Entertainment sobs, "You want to help, but you just can't help everybody. I feel worn down."

It is perhaps not surprising that scenes of heightened emotion stem from the boss's empathy towards those workers with similar experiences, such as dealing with addiction, immigration, healthcare costs for ailing or disabled family members or the recent loss of a parent. Featured workers often remind bosses of themselves or close family members. Put simply, the "otherness" of the working class is rendered familiar and less threatening, making the employee worthy of empathy and reward by a boss that converts "difference" into "sameness." In one episode, a university chancellor bonds with a Latina campus tour guide over the deaths of their respective fathers, both of whom died in automobile collisions. He 
tells the student that despite differences in skin color (the chancellor is markedly "whiter") "You and I are both Hispanic ... which means familia is very important to us." The erasure of differences in class, race and gender has a two-fold effect that enables the bosses to "connect" with staff and, moreover, position the struggling employees as poised for future success in the semblance of their employers. This is exemplified by the promise of personal mentorship presented by inspired CEOs of Checkers, DirectTV, Baja Fresh and 1-800-FLOWERS, for instance. Nearly all of the employees rewarded in the series share the boss's proclivity for diligence and dedication to the company as if it was "family."

While some bosses recall their "humble upbringing" and "blue-collar parents," the experience that most defies sublimation is that of being poor in the neoliberal now, when economic problems are attributed to personal failings and bad choices rather than structural inequality and the withering of social services. As the CEO of Taylormade Golf Company admits, "It's much more stressful for young people today than it was when I was young. I was playing golf in the summer, not working to make ends meet." At Mas Tec industries, the CEO learns of the large financial costs of caring for a disabled sibling from a disgruntled gas-line worker, who plans to get married when affordable. While the boss initially responds with "I've been married for thirteen years" (a tangential remark that slightly confuses the worker), he later tells the audience that "I haven't been in the position Rick is in. I haven't had to worry about providing something for my wife or my kids and to me it's important we don't let success get to our heads". The particularity of "being poor," of struggling to provide food, shelter and healthcare, is reframed as a general investment in family relations to which the boss can more readily relate. The nuanced experiences of poverty, physical labor, migration and caring for disabled children, for instance, are often reduced to what the boss generically describes as a "commitment to family." In Undercover Boss, capitalists cannot recognize laborers on their own terms.

The program's exposé of low-level employment and life under late capitalism also reveals (perhaps by accident) an inglorious underside of "multiculturalism," one that is forged from racialized and gendered divisions of labor in the US; mostly white male presidents and CEOs offer generous assistance to a low-level workforce comprised primarily of non-white and female employees. Women, immigrants and workers of color perform some of the more degrading yet demanding jobs in the series, from cleaning toilets in office buildings, emptying portable lavatories and picking litter at landfills to removing roadkill, pulling lettuce and packing vegetables in processing plants. The racial politics of labor and economic inequality - though unacknowledged in the series - are clearly reflected in the "minimum wage movement" and "a strategy of minority unionism" that has "set in motion thousands of working poor, mainly African American and Latinos (sic), who are acting collectively to better their lives" (Gupta, 2013). The widespread racialization of fast-food labor is often present in Undercover Boss, especially at Checker's, White Castle and Popeye's restaurants across the US where white managers oversee the daily operations of mostly black and Latina/o employees. But racial injustices are sequestered from a wider history of power relations in the US. At Kendall-Jackson wine estate, the white boss is concerned with language issues between the Anglo supervisor and Mexican campesinos, but seems oblivious to the long history of migrant worker exploitation from the Bracero Program (1942-1964) to "temporary foreign worker" initiatives that have overwhelmingly rewarded US agribusiness (Gonzalez, 1996). Here racialized relations of production are disconnected from "the cumulative effect of the historical sedimentation of unequal ... relations of power" and reframed as merely "communication issues" (Robbins, 2004). If the problems of the workplace are invariably disconnected from government regulations, unionization and social struggles in Undercover Boss, so too are the solutions, which resemble the practices of welfare capitalism of a bygone era.

\subsection{Welfare Capitalism Meets Neoliberalism}

Born of the industrial betterment movement, welfare capitalism in the US emerged in the early 1900s. After successive labor uprisings in the last three decades of the 1800s resulted in more than twenty-three thousand strikes and included nearly four million workers, industrial capitalists in the US - from Henry John Heinz and William Cooper Procter to John H. Patterson and Henry Ford-sought new management strategies that would quell labor conflict as well as circumvent government labor laws (Tone, 1997). The logic was such that if a corporation provided its workers with limited benefits-including housing subsidies, educational programs, leisure facilities, medical care, pensions and profit-sharing - it could stave off labor militancy and forestall looming government regulations of not only working conditions but also monopolistic practices among industrial capitalists (Meyer, 1981). Whereas welfare capitalism was relatively widespread by the 1920s, it was perhaps most advanced at the Ford factory in Highland Park. In 1914 Henry Ford introduced the Five Dollar Day, what Stephen Meyer describes as "the most famous labor-management reform in the annals of American business" (1981). Seeking to curb a four hundred percent rate of labor turnover and chronic absenteeism, Ford enlisted John R. Lee as Head of Personnel to oversee a series of reforms that "attempted to solve attitudinal and behavioral problems with an effort to change the worker's domestic environment" (Meyer, 1981). Under the Five Dollar Day program, factory workers at Ford received a portion of their wage through workplace productivity and another portion (deemed a profit-sharing incentive) by demonstrating attributes of an upstanding citizen: thrift, 
sobriety, cleanliness, self-discipline, punctuality and domestic responsibility. With the formation of the Ford Sociological Department, inspectors made impromptu visits to the homes of assembly-line workers to produce a "record of investigation" (Meyer, 1981). Such paternalism was especially acute towards immigrant workers, whose habits of personal hygiene and living conditions were often scrutinized by company investigators in highly-discriminatory ways. As Meyer explains, Ford's short-lived experiment with welfare capitalism "extended the frontiers of managerial control from the shop and factory into the homes and communities of Ford workers" aiming to remake "former European peasants into reliable and efficient factory workers" (1981).

Ultimately, Ford's paternalism and Five Dollar Day was seen as an invasive attempt to modify the social lives of workers (especially immigrants) that failed to change the drudgery of working conditions in the factory and the uncertainties of seasonal layoffs that threatened employee benefits. As a result, it was discontinued at Ford factories in 1921 (Meyer, 1981). Although welfare capitalism was in great decline (but far from dead) by 1930 and is now widely understood by labor critics as a corporate "sham" employed by capitalists when threatened by labor activism and abruptly discontinued when militancy subsided, there are three distinct but overlapping traits that reappear in Undercover Boss (Gitelman, 1992). Welfare capitalism: (1) used corporate "benevolence" to introduce new forms of disciplining labor beyond the workplace; (2) individualized workers to compromise class solidarity; and (3) relied on the rhetoric of "family" to discourage labor conflict and militancy. In each of these strategies, "employers strove to crush labor with kindness" (Tone, 1997).

Obviously, Undercover Boss performs a disciplinary role with undercover "agents" and camera crews claiming to film an unrelated reality television special (which becomes increasingly transparent to workers familiar with the ruse by the third season). The entire premise of the series is rooted in deceit and distrust of labor, relying on tactics redolent of the "company spies" at Ford's factories. What is less obvious, however, is how the narrative of corporate benevolence actually disciplines the worker. All of the employees rewarded in the series share similar attributes and embody self-responsibility, positivity, hard work and selfless dedication to both family and corporation. A fabricator at Yankee Candle is praised for "hard work and relying on himself" since "nobody's gonna do it for me"; a factory worker at Taylormade Golf Company is admired for not "hiding behind [the excuse that] ... life's dealt you a bad hand"; a customer care worker at DirectTV is described by her employer as "a very self-disciplined person who has an incredible ability to put adversity behind her." Through reward and reprimand, the series presents a rather narrow definition of the "good worker" and US citizen that privileges the interests of capital. Though not inherently problematic, traits like self-discipline, thrift, and do-it-yourself (DIY) ethics become thorny when paired with a neoliberal logic that maintains (against insurmountable post-2008 evidence to the contrary) that social and economic ills are best cured by marketplace solutions, provided one can afford the increasing expenses of privatized healthcare and social services (McDonough, Reich \& Kotz, 2010). It assumes a "level playing field" in social and economic life whereby individual perseverance is privileged and failure to achieve and "win" is pathologized.

In Undercover Boss, workers and employers constantly remind us that "life is what you make of it" and how "you can't let a lack of resources get in the way of moving forward." This is most prominent and problematic with the depictions of workers with a disabled family member, which epitomize the "good" neoliberal subject that "manages to get by without welfare and government services in spite of difficult situations" (Ferrier, 2005). A window-washer at ABM and a parking-enforcer at the City of Cincinnati, for example, have children with Cerebral Palsy who require constant and costly care as well as modified transportation; a White Castle employee has a visually-impaired son that needs specialized educational resources; a screen-printer at O'Neill Clothing cares for a daughter with Cornelia de Lange Syndrome that requires expensive leg braces; a waitress at the Tilted Kilt and a dispatcher at Roto-rooter struggle to afford treatment for their respective autistic children. Though the disabled child is not always an "absent-subject" in the series - a teenager with Asperger whose mother works at PostNet outperforms the company's unsuspecting CEO—s/he is typically used as a form of what Stella Young calls "inspiration porn" to extol the virtuous caregiver. At the same time the program exposes the "hidden" costs of trademark neoliberal reforms like cutbacks to disability services and company health benefits, it objectifies disability as a narrative prop used to define the good worker in rather precise terms as one that cares for the "less-fortunate" and asks for neither compensation nor compliments.

Through praises, prizes and promotions, the viewer is invited to distinguish between "good workers" and those that require retraining, like etiquette lessons for a pot-smoking ne'er-do-well at O'Neill. Undercover Boss tells us that "bad workers" share attributes opposed to "customer service" and corporate acquiescence. They are predisposed to frequent "smoke breaks," express frustration with customers and refuse to "up sell" items. Some of the "bad workers" are openly dismissive of the products they sell, like the retail clerk at O'Neill appalled by the childish designs of the company's clothing. At Boston Market, one employee with an "attitude problem" (boss's description) is fired for making disparaging remarks about guests and berating the company's policy of "the customer is always right." While the employee is indeed crass, he is not asked to articulate his frustration with Boston Market and the service industry. He 
does, however, touch on the indignities of "servitude" and the dehumanizing aspects of his job by telling the "new recruit" that "we don't ask questions we just act like robots". At United Van Lines, a warehouse worker is shown to be lethargic and indifferent but is reprimanded mostly for questioning the chain of command. As the CEO later reflects in disbelief, "I've never seen anyone say 'no' to their boss before." Each of these workers is either dismissed or "retrained" for their indifference and irreverence. And yet the "bad worker" more often appears through discursive silences surrounding "union talk," collective bargaining, social justice and labor organization. A lift mechanic at Squaw Valley ski resort receives recognition by the CEO for "keeping [his] head down" and "just doing [his] job"; a baker at 7-11 is praised for just "making donuts and having fun" and abstaining from "corporate talk." While almost all employees voice concerns about working conditions, plant closures, communications and pay, Undercover Boss and the narrative of corporate benevolence prohibits an understanding of class as a social formation, much less one informed by organized labor. The series, in other words, individualizes to depoliticize, a noted attribute of welfare capitalism.

Whereas welfare capitalism of the early twentieth century initiated company-wide policies and provisions, the "benevolence" of Undercover Boss is administered on an individual basis, providing a more neoliberal approach to corporate paternalism. Workers are separated throughout the episode as they discuss job dissatisfaction and family life with the boss on lunch breaks and meet with the CEO or president one-on-one rather than collectively. As Nick Dyer-Witheford suggests, "capital must strive to decompose or break up" threatening groups of workers at the same time it relies on their cohesion, cooperation and collectivity to produce commodities (1999). As the company and CEO "redress grievances on an individual rather than a collective basis" they undermine collective labor power and resist the application of amendments and improvements throughout the company (Cohen, 1990). As Lizbeth Cohen points out, the strategy of isolating workers under welfare capitalism was designed to make employees "solely dependent" on their bosses (1990). Rather than provide company-wide revisions or additions to benefit packages, the boss doles out cash in one easy installment to only a select few. But if welfare capitalists sought to avoid government labor regulations by caring for workers on the company's terms, Undercover Boss works to free the executives from the company-wide obligations of welfare capitalism. Herein lies a streamlined neoliberal version of corporate paternalism overshadowed by the spectacle of generosity in the gift-giving ceremony, which isolates the worker in a "feel good" story.

At the same time Undercover Boss isolates workers, however, it also encourages employees to think of the company as "family," a buzzword of welfare capitalism. From emotional reflections on deceased loved ones and the struggles of single parents to recurring references to children with disabilities and absent fathers, Undercover Boss is nothing if not "family-centric." While the bosses are obviously interested in company performance, they are all shown on the homestead enjoying leisure activities with partners, children and pets on sprawling estates. While such scenes showcase wealth and prosperity in "tough economic times", they also establish the sincerity and character of the boss, who is presented as a good parent and loving partner committed to both kin and company. The emphasis on "family" continues throughout each episode as disguised bosses broach conversations with employees by asking of their families. The objective of many employers featured in Undercover Boss is to either maintain or recover the "family sensibilities" of the corporation, which have apparently gone astray during the Great Recession. Indeed, bosses often encourage employees to consider the company as a surrogate, one that allegedly provides a suitable substitute for estranged kin. As the boss of Choice Hotels explains to an employee, "I know your family never gave you support. I want you to think of Choice as your family for a long time." The boss later explains during the final "pep rally" how "We are all part of the Choice family." At a similar rally the CEO of Great Wolf Lodge is introduced as "Mamma Wolf, the head of our family." A co-owner of the Chicago Cubs suggests that within the organization, "We are all one family". The president of Lucky Strike Lanes goes so far as to describe the company as "a child that my wife and I birthed and now has been adopted by a lot of people". He adds that "Lucky Strike is all about family and that's why [employees] work." At the pep rally for Roto-rooter, a black employee is reluctant to hug his white boss until the CEO cajoles, "Henry? C'mon. Family! Family"!

While the rhetoric of family clearly builds the emotional commitment of the series - and is compounded by the gift-giving ceremony that caters to families in need-it further depoliticizes the workplace. As Gerald Zahavi explains of welfare capitalism:The family connoted harmony, security, authority, and stability - all values the corporation sought to develop and exploit. It was a powerful metaphor, both a confining and comforting image, one that promoted the internal resolution of conflict. The transposition of the employer into a father figure was aimed at making industrial protest and rebellion the equivalent of patricide (1988).

Given the pervasiveness of the family metaphor in Undercover Boss, it is little wonder discussions of unions and organized labor are almost entirely absent from the series. Here public litigation is anathema to private familial relations, suggesting that the caring parent/CEO will ultimately provide for employees without the need to organize and campaign. By appealing to "family matters," the bosses encourage the resolution of labor conflicts on their own terms rather than standards imposed by government regulations or collective bargaining agreements of unions. 
But the series is compelled to expose a critical snag in the rhetoric of neoliberalism such that capitalism is both the problem and the purported solution to the struggles of individual workers. This is especially apparent at 1-800-FLOWERS where the president learns the pressures of the factory and promises to let assembly workers help determine production quotas, yet in the same breath offers incentives to exceed those quotas. As the series is clearly empathetic towards the destitution of some employees it ends up "decoupling" the "personal" from the "social", presenting to the viewer a series of isolated problems that can best be resolved through the marketplace in general and the warmhearted capitalist in particular (Robbins, 2004). The solution to mounting bills and travel expenses to and from work is a new vehicle for two employees at Dwyer Group and Diamond Resorts; employees with ill or disabled children find refuge in generous bonuses rather than "Obamacare." That the series fails to provide alternatives to capitalism as an exploitative mode of production may signal what Mark Fisher calls "capitalist realism" (2009). Fisher's term describes what he and other social theorists perceive as a dearth of political imagination on the left and "the widespread sense that not only is capitalism the only viable political and economic system, but also that it is now impossible even to imagine a coherent alternative to it" (2009).

The ruse of capitalist realism, however, is rather flimsy in Undercover Boss. Upon receiving their "gifts," many employees respond in ways that potentially disrobe the mythical nature of the intervention and the overarching fantasy of Undercover Boss as a "capitalist fairy tale." At the end of several episodes, bosses are described as "saintly" when employees refer to the gestures of gift-giving as a "blessing" or a "miracle." A Yankee Candle employee even suggests that her boss "needs a little set of angel wings and a halo" for covering \$20,000 in medical expenses and a family vacation. Other employees "thank the lord" and "praise Jesus" for the good fortune and "miracle" granted to them. Based on these reactions, many employees situate the boss's goodwill as an act of divine intervention rather than a product of capitalist relations of production. It cannot possibly emerge from the same system that overworks and underpays them. Similarly, other employees describe their workplace rewards as akin to "winning the lottery," an equally revealing fiction of accumulating wealth and prosperity. After receiving more than $\$ 25,000$ in gifts for her hard work, an emergency dispatcher at ADT Security claims, "I can buy [my son's] school pictures. I can buy groceries. This is like winning the lottery and I didn't even play". Another worker at Fatburger is astonished by her boss's gift of tuition for nursing school and a $\$ 10,000$ honeymoon and explains, "I get excited when I win $\$ 3$ in scratcher tickets. This is much better." While not all employees praise god and good fortune, the regularity with which "Jesus" and "jackpots" are invoked suggests that the solutions proposed by Undercover Boss are situated by the recipients as unbelievable, surreal and extrinsic to the social structure of accumulation in which the series aims to support. Workplace improvements and prosperity among the working class are as likely to occur as experiencing a miracle or winning the lottery (odds of which are 1 in 28.6 million).

\section{Conclusion}

There are, of course, no gift-giving ceremonies for the workers and activists behind Fight for Fifteen, Fast Food Forward and other "alt-labor" movements that represent the increasingly clamorous demands and struggles of low-wage employees in North America. As Arun Gupta argues in In These Times, "One of the key factors in labor's decline has been the growth of the non-unionized service sector, where low wages have become the norm and workers who try to organize often face retaliation" (2013). In the US, for instance, no workers at fast-food franchises are unionized, a phenomenon labor activists are attempting to change (Gupta, 2013). Given the program's interest in service-sector employment, it is perhaps not surprising to find a disinterest if not deafness regarding organized labor in Undercover Boss. The series is silent on government labor legislation, a rejuvenated welfare state or the workers' movements that currently target fast-food and service industries in the US. The program's solutions are drafted in the lexicon of welfare capitalism that endorses rather than contests the market as a source of economic and social provisions.

For all its pro-capital messages that seem to dismiss the claims of current service labor movements, Undercover Boss also unwittingly supplements the struggles of Fast Food Forward and Fight for Fifteen in various ways. The program itself is haunted by a central dialectic: the "benevolent" boss that "resolves" the quandaries of late capitalism can only emerge against a backdrop of adverse working conditions, which the series is obliged to address in passing but also in perpetuity for its own success. While Undercover Boss may present a "capitalist fairy tale," it also serializes many of the problems of low-level employment and life under late capitalism, presenting issues of low wages, long hours and general economic inequalities as pervasive and troubling. Reading Undercover Boss as a serial melodrama, however, requires some tricky maneuvering. On the one hand, the viewer's recognition of Undercover Boss as a serial melodrama and by extension the commonality of labor relies on an abstraction of individual workers in discrete industries, which reduces and obfuscates qualitative differences in performance and degrees of exploitation as well as divergent histories of struggle "that present the most formidable barriers for the organization of counterpower" (Dyer-Witheford, 2001). Both the workers and the bosses are reduced to generic characters for entertainment purposes.

On the other hand, it is the abstraction of labor that provides a possibility for recognizing the pervasiveness of 
exploitation and potential for mobilization or what Michael Hardt and Antonio Negri might call the "becoming common of labor" (2004, p. 103); the crisis condition of inequality undergirds labor-capital relations at not only MGM Grand, Chiquita produce plants and Fatburger restaurants, but across all service, fast-food and manufacturing industries featured in Undercover Boss. In short, the closure and compromise promised by each episode is endlessly deferred by the perpetuity of the series itself. It is the hybrid blend of genres in Undercover Boss that invites nuanced analysis, especially of the requisite "gift-giving" that resembles an outdated version of corporate paternalism and welfare capitalism. As Ed Rooksby suggests, "the way to combat capitalist realism is to identify and tease out its gaps, tensions and contradictions" (2012). It is within the least likely venue of corporate television and neoliberal narratives of reality programming that we find a series of self-engendered paradoxes that lend themselves to a wider critique of working conditions under late capitalism.

\section{References}

Andrejevic, M. (2004). Reality TV: The work of being watched. Rowman and Littlefield: New York.

Boyle, K., \& Mrozowski, D. (eds.) (2013). The Great Recession in fiction, film, and television: Twenty-first century bust culture. Lanham, MD: Lexington Books.

Brayton, S. (2012). Working stiff(s) on reality television during the Great Recession. Societies, 2(4) (Special issue: Embodied Action, Embodied Theory), 235-251.

Chouliaraki, L., \& Fairclough, N. (1999). Discourse in late modernity: Rethinking critical discourse analysis. Edinburgh, UK: Edinburgh University Press.

Cohen, L. (1990/2008). Making a new deal: Industrial workers in Chicago, 1919-1939 (2nd Ed.). Cambridge, MA: Harvard University Press.

Davies, Lyell. (2013). Workers' confessions and the reality TV series Undercover Boss, Jump Cut, 55, 1-18. http://www.ejumpcut.org/currentissue/lyellDavUnderBoss/

Dyer-Witheford, N. (1999). Cyber-Marx: Cycles and circuits of struggle in high-technology capitalism. Urbana and Chicago, IL: University of Illinois Press.

Fairclough, N. (1995). Media discourse. London, UK: Edward Arnold.

Ferrier, L. (2005). Benevolence and gift-giving in Backyard Blitz. Journal of Australian Studies, 85, 11-25. http://dx.doi.org/10.1080/14443050509388012

Fisher, M. (2009). Capitalist realism: Is there no alternative? Winchester, UK: Zero Books.

Gabbatt, A. (2013). US fast-food workers strike over low wages in nationwide protests, The Guardian, 5 December.

Gitelman, H.M. (1992). Welfare capitalism reconsidered, Labor History, 33, 5-31. http://dx.doi.org/10.1080/00236569200890011

Greenhouse, S. (2013). A day's strike seeks to raise fast-food pay, New York Times, 31 July. Retrieved 20 April 2014. http://www.nytimes.com/2013/08/01/business/strike-for-day-seeks-to-raise-fast-food-pay.html?pagewanted=all\&_ $\mathrm{r}=0$

Gupta, A. (2013). Fight for fifteen confidential, In these times, 13 February. Retrieved 20 April 2014 from http://inthesetimes.com/article/15826/fight_for_15_confidential

Hardt, M., \& Negri, A. (2004). Multitude: War and Democracy in the Age of Empire. New York, NY: Penguin Books.

Havrilesky, Heather. (2010) Undercover Boss: Capitalist fairy tale, Salon, 4 February. Retrieved 5 February 2014 from http://www.salon.com/2010/02/04/cbs_undercover-boss-fairly-tale/

Hearn, A. (2006). John, a 20-year-old Boston native with a great sense of humour: On the spectacularization of the "self" and the incorporation of identity in the age of reality television. International Journal of Media and Cultural Politics, 2(2), 131-147. http://dx.doi.org/10.1386/macp.2.2.131/1

Horovitz, B. (2014). Fast-food worker strike about to go global, USA Today, 7 May. Retrieved from http://www.usatoday.com/story/news/usanow/2014/05/07/fast-food-worker-strike/8803193/.

Jacoby, S. (1997). Modern manors: Welfare capitalism since the New Deal. Princeton, NJ: Princeton University Press.

James, O. (2008). The selfish capitalist: Origins of affluenza. London, UK: Vermillion.

McDonough, M. Reich \& D. Kotz (eds.), Contemporary capitalism and its crises, 72-90. Cambridge, UK: Cambridge University Press.

McDonough, T., M. Reich \& D. Kotz. (2010). Introduction: Social structure of accumulation theory for the twenty-first 
century. In T. McDonough, M. Reich and D. Kotz (eds.), Contemporary capitalism and its crises, 1-22. Cambridge, UK: Cambridge University Press.

McMurria, J. (2008). Desperate citizens and good Samaritans: Neoliberalism and makeover reality TV. Television and New Media, 9, 305-332. http://dx.doi.org/10.1177/1527476408315115

Meyer III, S. (1981). The five dollar day: Labor management and social control in the Ford Motor Company, 1908-1921. Albany, NY: State University of New York Press.

Mittell, J. (2013). "Serial melodrama". Complex TV. Retrieved 25 May 2014 from http://mcpress.media commons.org/complextelevision/serial-melodrama/

Murray, S., \& Ouellette, L. (2004). Introduction. In S. Murray and L. Ouellette (eds.), Reality TV: Remaking television culture, 1-15. New York, NY: New York University Press.

Nunn, H., \& Biressi, A. (2010). Walking in another's shoes: Sentimentality and philanthropy on reality television. In L. Ouellette (ed), A companion to reality television , 478-497. Oxford, UK: Wiley Blackwell.

Ouellette, L., \& Murray, S. (2004). Introduction. In S. Murray and L. Ouellette (eds.), Reality TV: Remaking television culture , 1-15. New York, NY: New York University Press.

Raphael, C. (2004). The political economic origins of reali-TV. In S. Murray and L. Ouellette (eds.), Reality TV: Remaking television culture , 119-136. New York, NY: New York University Press.

Retrieved20 April 2014 from http://www.theguardian.com/world/2013/dec/05/fast-food-workers-strike-minimum-wage.

Robbins, C. G. (2004). Racism and the authority of neoliberalism: A review of three new books on the persistence of racial inequality in a color-blind era. Journal for Critical Education Policy Studies, 2(2). Retrieved 25 April 2014 from http://www.jceps.com/print.php?articleID=35

Rooksby, E. (2010). Review of Capitalist realism: Is there no alternative? Historical Materialism, 20(1), 222-231. http://dx.doi.org/10.1163/15692061X632827

Striffler, S. (2010). Media review: Undercover Boss, Labor, 9.4, 83-85. http://dx.doi.org/10.1215/15476715 1726054

Tone, A. (1997). The business of benevolence: Industrial paternalism in Progressive America. Ithaca, NY: Cornell University Press.

Wolfson, M. H., \& Kotz, D. (2010). A reconceptualization of social structure of accumulation theory. In T.

Wood, H. \& Skeggs, B. (2008). Spectacular morality: reality television, individualization and the remaking of the working class. In D. Hesmondhalgh and J. Toynbee (eds.), The Media and Social Theory, 177-193. London, UK: Routledge.

Zahavi, G. (1988). Workers, managers and welfare capitalism: The shoeworkers and tanners of Endicott Johnson, 1890-1950. Urbana and Chicago, IL: University of Illinois Press.

----. (2003). Analysing discourse: Textual analysis for social research. London and New York: Routledge.

\section{$(\mathrm{cc}) \mathrm{BY}_{\mathrm{B}}$}

This work is licensed under a Creative Commons Attribution 3.0 License. 